\title{
Establishing an Atmosphere for Critical Thinking in the Online Classroom
}

\author{
Ronald G. Steadman \\ Metacognition and critical thinking are crucial elements in the educational process. The following article examines the use \\ of a quiz/poll classroom assessment technique (CAT) in a 100-level Christian worldview classroom (CWV-101) designed to \\ stimulate student engagement with the course principles in a self-reflective and non-threating environment, thus establishing \\ an atmosphere for critical thinking. The quiz/poll CAT is explained and its underlying inspiration explored.
}

to provide insight on the effectiveness of classroom assessment techniques in the online environment.

\section{ESTABLISHING AN ATMOSPHERE FOR CRITICAL THINKING IN THE ONLINE CLASSROOM}

This paper will discuss a quiz/poll classroom assessment technique (CAT) developed for use in a 100-level Christian worldview class (CWV101) designed to encourage student engagement with the course principles from the earliest stages of the course. Worldview assumptions are often held without cognitive processes; assumptions are adopted unknowingly without critical analysis as to the consistency, authenticity, and livability of those beliefs (Cosgrove, 2006). This paper will explore the importance of critical thinking that leads to metacognitive behaviors, specifically relating to their essential nature in the development of a cogent worldview.

An overview of the premises underlying the development of this quiz/poll will be followed by an explanation of the inspiration that led to its development and an analysis of the quiz/poll itself. The results from the use of the quiz/poll in classrooms facilitated by this instructor will demonstrate the viability of adapting the outlined methodology to other academic disciplines to engender student engagement with, and analysis of, core concepts.

Metacognition is a primary component of the educational process. Students are learners; successful learning occurs when students are equipped to apply knowledge strategically to meet goals (Livingston, 2003). Those who have developed metacognitive abilities reflect on their thinking as they perpetuate the learning process (North Central Re- gional Educational Laboratory [NCREL], 1995).

Metacognition, however, is only part of a wellrounded education; knowledge must also be analyzed and applied through critical thinking in order for maximum benefit to be realized. Metacognition equips the student to derive greater benefit from instruction (Livingston, 2003). Critical thinking enables the student to evaluate available options, analyze the credibility of sources, assess positions by asking questions and analyzing arguments, and draw valid conclusions as they continue the investigative process (Criticalthinking.net, 2012). Metacognition equips the student with "active control over the cognitive processes" (Livingston, 2003, p. 2). Critical thinking forces the student to analyze information and apply it in a relevant manner (Criticalthinking.net, 2012).

As instructors approach their classrooms, they are faced with a challenge: teaching curriculum in a manner that students not only learn the curriculum at a metacognitive level, but also encourages them to think critically about the knowledge and its value to real life situations. Knowledge must be understood through "introspective thought" (Bailey, 2012) as it is analyzed and applied through critical thinking. The mind of the student must be engaged with the curriculum for metacognition and critical thinking to occur.

Stauffer's Frozen Lasagna (2014) aired a television advertisement early in 2014 that captured the essence of the dilemma faced by modern educators - attracting the focused attention of young men 
and women living in a technological age. In this advertisement, a teenage girl is shown engrossed in communicating with her friends via her cell phone as her mother prepared dinner and placed it on the table. The teenager ate one bite of the Stauffer's Lasagna and laid her cell phone aside, even ignoring its ring to the amazement of her parents as she indulged in the tasty meal (Stauffer's Frozen Lasagna, 2014). Something captured her undivided attention!

In the contemporary online classroom, the instructor must find methods that present the subject matter in a manner that captures the focused attention of the student while the student learns material that will better prepare her or him to meet the challenges of the world and its imperfections (Cosgrove, 2006; Gaeddert, 2003). Designing tasty meals for student consumption that attracts the student's attention and creates an atmosphere for metacognition that results in critical thinking is no easy task.

\section{OVERVIEW}

For the online instructor, it is not enough to master the curriculum and its applications. The information must be presented in a manner that helps the student understand he or she is better prepared for life with this knowledge. The material must capture the imagination if it is to be deemed salient and worthy of inculcation into the student's life.

The following explanation will focus on capturing the student's interest through the use of a quiz/ poll in the initial stages of an online classroom. The quiz/poll, which is the subject of this paper, was developed for use in a 100-level Christian worldview course (CWV-101) with a multi-tiered objective: (1) capture the students' interest, (2) allow the students to self-assess individual perspectives through a non-confrontational process, (3) encourage critical thinking, and (4) provide a framework for further analysis and interaction.

While identifying personal assumptions and formulating cogent positions regarding beliefs are characteristics of a critical thinker (Criticalthinking.net, 2012), they are also sensitive endeavors that need to be done in a reflective and non-threatening atmosphere. This quiz/poll was created as a vehicle through which students can self-reflect on and self-assess the assumptions they hold and the relationships between underlying assumptions and well-formulated beliefs. Critical analysis of held assumptions was intended to aid the students in making the connection between, 'I assume this to be true' to are my "thoughts an accurate reflection of reality?" (Bailey, 2012). "Learning is a complex process ... it involves not only knowledge and abilities but values, attitudes, and habits of mind that affect both academic success and performance beyond the classroom" (Astin et al., 1996, p. 1).

Preparing students for "both academic success and performance beyond the classroom" (Astin et al., 1996, p.1) was the goal of the quiz/poll presented and explained. Each academic discipline and individual classroom strives to achieve its part of this overarching goal. Therefore, the suggested method can be adapted to each academic discipline through a careful analysis of the core principles of that discipline and a reflection on the obstacles that inhibit the student from full engagement in the course materials.

\section{ACADEMIC FOCUS}

Rote learning is only the initial stage in education. Learners must be able to think critically as they apply learned knowledge to identify problems and seek solutions (Kelley, McGraw, \& St. LouisSanchez, 2014). Implicit in the 50 CATs developed by Angelo and Cross (Angelo \& Cross, 1993) and in Gaeddert's reflection on Lowman's 1996 research that "instructional practices must interact with strategic learning practices for learning to occur" (Gaeddert, 2003, p. 48), is the centrality of critical thinking to the educational process; metacognition and analytical application are in focus.

Learning occurs when the student is able to practically apply the lessons of the classroom in their chosen discipline. Helping students develop critical thinking skills is vitally important for the university as it prepares young men and women to succeed in and influence the world; it carries a special emphasis for the Christian university as it prepares young men and women to act as the Lord's ambassadors as they succeed in and influence the world.

\section{CORE CONCERNS FOR THE CHRISTIAN UNIVERSITY}

Critical thinking aims at its core to help individuals reach informed and valid conclusions. If the base from which an individual draws for their analysis is faulty, the conclusions drawn will yield 
little benefit. The Christian university is charged with teaching accurate academic information in an atmosphere that challenges students to look to universal truth for analysis and application. Ravi Zacharias (2001) succinctly phrased this idea with, "Truth demands investigation and commitment. Our conclusions must be in keeping with Truth that can be tested. To be handcuffed by a lie is the worst of all imprisonments" (p. 8). A truth claim, be it scientific, religious, or philosophical, by its very nature invalidates truth claims that are antithetical or contradictory in nature and substance (Groothuis, 2000). Academic excellence joined with ultimate truth is the goal of the Christian university.

Jesus had no problem attracting the attention of His disciples (John 1:44-49; Matthew 5:1), of the masses (Luke 6:17; Mark 1:45; Matthew 5:1; 8:18), or of those who opposed His teachings (Matthew $4: 3 ; 8: 34 ; 22: 15-18)$. Therefore, the methods He employed should be considered and analyzed by instructors in designing lessons for the contemporary classroom. Modern technologies and instructional methodologies have yielded, and will continue to yield, new avenues through which the educator can interact with the interest of students. With a goal of attracting the focused attention of students to stimulate their thought processes and the commitment to integrating the lessons of the classroom to life situations, much can be learned from Jesus - the great teacher. Integrating the wisdom of teaching exhibited by Jesus with modern technologies and methodologies in the online classroom can yield the best of both.

\section{PREMISE FOR THE METHODOLOGY}

Jesus often taught using parables, "primarily designed to instruct” (Pentecost, 1982, p. 9). Fee and Stuart (2003) added that there was a "clear implication that the parables were to be understood" ( $p$. 150 ). According to Dodd (as cited in Klein, Bloomberg, \& Hubbard, 2004), Jesus' parables extended beyond the simple story to include other forms of instructive comparisons that are "drawn from nature or common life" (p. 412). Dodd (as quoted in Klein, Bloomberg, \& Hubbard, 2004) went on to explain that the parables captured the attention of Jesus' audiences and engaged their minds, teasing them "into active thought" (p. 412). It is this understanding that led to the development of the quiz/ poll that is the subject of this writing. Tapping into common experiences and perceptions in a manner that stimulates "active thought" (Dodd, 1935) is critical thinking.

\section{DEVELOPMENT AND EVALUATION}

Example 1 (see Appendix A) contains a copy of the quiz/poll posted in the discussion forum of recent CWV-101 classrooms facilitated by this author. The quiz/poll was developed and amended over several sessions of CWV-101, incorporating student responses and student feedback on the quiz/poll itself. The amended quiz/poll demonstrated the importance of student feedback and of incorporating that feedback in the teaching/learning process (Gaeddert, 2003, p. 51). The Advisory Committee for Academic Assessment at Kent State University (n.d.) illustrated the need for continued reassessment with a wheel outlining the process as "Identify Goals, Identify Objectives, Specify Approaches, Specify Measures, Share Results, Makes Changes, Identify Goals, and so forth."

Feedback from students in future classes may result in further revisions to this quiz/poll. The version presented in Example 1 resulted in active student participation. Response rates ranged from a low of $68 \%$ (17 out of 25 students) to a high of $100 \%$ (27 out of 27 students) and extended conversation regarding the underlying principles of worldview, which was the subject of the course in which this quiz/poll was placed. There was commonly extended conversation regarding the distinction between perception and reality. Students advocated that perception is reality without considering the ramifications of a world in which reality is determined by individual perceptions.

\section{THE QUIZ/POLL}

This quiz/poll was designed to stimulate thought and further discussion regarding specific philosophical questions inherent in the study of worldview, among which are: (1) Do underlying assumptions affect a person's perceptions, attitudes, actions, and interactions?; (2) Does truth exist?; (3) Do people live life as if there is a known reality?; and (4) Are the worldview assumptions of a source important in analyzing and assessing the data they assert? Because worldview assumptions are often held without consideration as to their internal consistency, livability, or reflection of reality, students must be challenged to think critically as they 
analyze the underlying assumptions that influence their worldview (Cosgrove, 2006). Following is an explanation of the thought processes behind each question and how that question was intended to stimulate thought and conversation regarding one of the preceding questions.

\section{SOCIAL SCENARIO}

Question 1 developed from the concept of a parable in the sense that it contained a scenario with which most in our society can identify - the purchasing of a gift for the wedding of a close friend or relative. Students were asked to respond by selecting one of five options (a, b, c, d, or e) that covered a wide range of available responses to the presented scenario. A possible real life scenario was presented to which the student determined what they deemed as the best solution. This question was designed to help the student understand the relationship between perception and reality. Although each student may have perceived the need to monitor the child differently, reality was obvious in the existence of the store, the need for the gift, and the presence of a young child. The distinction between perception and reality was explained in the results post but not overtly declared in the initial quiz/poll.

\section{A RELATABLE SITUATION}

Questions 2 and 3 related to reality and perception. Questions 2 and 3 presented a scenario of common reference - the purchasing of a ticket from a major league ticket office and attending a sporting event at a major league ballpark. Reality was assumed in that the organization issuing the ticket was a real entity and the stadiums contained real seats. Perceptions were addressed in the perceived authenticity of a ticket purchased from a major league organization and in the trustworthiness of seats in a major league ballpark. As in question 1, the intended correlation between reality and perception was explained in the results post but not overtly declared in the initial posting.

\section{COMMON ASSUMPTIONS CONSIDERED}

Question $4 \mathrm{a}$ and its sub-question $4 \mathrm{~b}$ and question 5 related to underlying assumptions that were often not analyzed as to their validity but wielded considerable influence in addressing the issues of life. Question $4 \mathrm{a}$ was a statement to which students were asked to indicate the extent of their agreement or disagreement. Its sub-question $4 \mathrm{~b}$ asked students to "Briefly explain your rationale" (see Example 1). Paraphrases of sample responses to sub-question $4 \mathrm{~b}$ were included in Example 2 (see Appendix B), which was indicative of often unrealized worldview assumptions. Like question 4, question 5 also made a statement and asked students to indicate the extent of their agreement or disagreement with the statement. Questions $4 \mathrm{a}$ and 5 were specifically designed to challenge students to analyze the statements and think critically about its implications.

\section{SOURCE AND CONTEXT}

Questions 6 and 7 related to information and its sources. Implicit in these questions was whether or not assertions can be understood and accepted apart from the worldview and motivations of the one making the assertions. Students who responded that they agree with the statement and that the source of the quote made no difference in their answer have not demonstrated critical thinking skills. Information was inextricably tied to its source. Valuable information can be derived from many sources, regardless of the worldview assumptions of the espouser of the information; however, interpretation and application of information is linked to worldview assumptions. The underlying question that must be asked and answered is, "How do the worldview assumptions and motivations of the source influence the conclusions drawn and application(s) proposed?" The source for the quote of question 6 was not revealed in the initial posting (see Example 1) in an effort to avoid bias prior to the consideration of the words and their import (the speaker and source were revealed and cited when the results were posted - see Example 2).

\section{FOLLOW-UP}

When the results of the quiz/poll were posted in the discussion forum (see Example 2), followup questions were included to stimulate further dialogue and analysis of the quiz/poll and student responses. Simply posting the tabulated results, coupled with the intended link between the questions and follow-up questions, reassured students the exercise was intended to stimulate critical thinking and analysis. This method indicated that students were valued as individuals. Because the beliefs associated with a worldview were deeply held and often unrealized, it was important that 
students felt valued rather than berated. Vehicles, such as the one described, attempted to subtly challenge students to think critically about the views they espouse.

Further analysis of the consistency of the individual students thought process as it related to worldview assumptions were subtly encouraged through the stimulus this quiz/poll provided.

The results derived from this quiz/poll were extremely encouraging, generating responses from well over half of the class. The results indicated that the minds of the students are engaging with the principles of the course, a necessary initial step in critical thinking. Response rates ranged from a low of 17 out of $25(68 \%)$ to a high of 27 out of $27(100 \%)$, while other CATs generated responses from 2 out of $25(8 \%)$ to 10 out of $25(40 \%)$. The responses to the final follow-up question of the results post (Example 2), "Did you enjoy this exercise?" were even more encouraging. Many students indicated a desire for more such exercises and those who indicated such a desire tended to respond to additional postings. Those students also exhibited a greater engagement with the material in their discussion forum posts throughout the course.

Another encouraging result from both the quiz/ poll (Example 1) and the results post (Example 2) was the substantive nature of student responses. In the initial quiz/poll, students were asked to supply a written response to only one question, "Briefly explain your rationale" (Example 1, 4b). The majority of the answers to this question could be grouped into two broad categories: (1) students who adopted a post-modern philosophy that rejected absolute truth (Groothuis, 2000) and (2) students who believed that absolute truth exists and is knowable (Corduan, 2007, Groothuis, 2000). Regardless of their answer to question 4a, students were willing to articulate why they answered as they did using correlations to other classes, previous experience, and family situations - all of which were elements of substantive responses. Although some students demonstrated inconsistency in their reasoning, they were forced to articulate their thoughts and reflect on what they wrote.

Self-analysis and self-reflection assisted the student in further evaluating their worldview analytically as the study progressed. If walls were erected, students tended to reject information without consideration. The quiz/poll that is the subject of this writing was not designed to immediately refine student thinking; it was designed to establish a comfortable atmosphere and stimulate student critical thinking. Refinement comes as the course principles are introduced, discussed, and either accepted or rejected by the individual student.

\section{CONCLUSION}

Moving forward, the questions posed and the underlying principle associated with each question will vary according to the academic discipline. Each academic discipline and individual classroom has specific concerns for needed focus. The specific questions and their underlying purposes for this particular quiz/poll were offered in explanation of the thought process of this instructor and the benefit such quiz/polls had in stimulating critical thinking in the online classroom. The study of worldview is a concept with which many are unfamiliar. Some students entered the study with a closed mind, asserting from the outset that their beliefs were private and no one would change those beliefs. A closed mind cannot engage the course material with critical thought and analysis.

The use of the quiz/poll outlined above early in class served to break down some barriers and encourage students to engage the materials. It was also designed to stimulate the students in understanding the importance of the study; students did not analyze information they deemed unimportant. Breaking down barriers and engaging student minds early in class helps to create an atmosphere in which critical thinking can occur and alerts the instructor to areas that need greater focus as the class moves forward. Class add-ons, such as the one described, help students engage in the course materials at an analytical level and assist the instructor by creating greater student interaction with the materials. 


\section{References}

Angelo, T. A., \& Cross, K. P. (1993). Classroom assessment techniques: A handbook for college teachers. San Francisco: Jossey-Bass.

Black, P., \& William, D. (1998). Inside the black box: Raising standards through classroom assessment. Phi Delta Kappan, 80, 139-148.

Boston, C. (2002). The concept of formative assessment. Practical Assessment, Research \& Evaluation, 8(9). Retrieved from http:/l PAREonline.net/getvn.asp? $v=8 \& n=9$

Carr, E., \& Ogle. D. (1987). K-W-L plus: A strategy for comprehension and summarization. Journal of Reading, 30(7), 628-631. Retrieved from http://www.jstor.org/stable/40031872.

Clark, I. (2012). Formative assessment: Assessment is for self-regulated learning. Educational Psychology Review, 24, 205-249.

Evaluation research. (2001). In Reader's Guide to the Social Sciences. Retrieved from www.credoreference.com/entry/routsocial/evaluation_research

Henderson, T. (2001). Classroom assessment techniques in asynchronous learning networks. Retrieved from http://sloat.essex.edu/ sloat/delete/contentforthewebsite/classroom_assessment_techniques.pdf

Nicol, D., \& Macfarlane-Dick, D. (2006). Formative assessment and selfregulated learning: A model and seven principles of good feedback practice. Studies in Higher Education, 31(2), 199-218.

Ragan, L. C. (n.d.). 10 principles of effective online teaching: Best practices in distance education. Faculty Focus. Retrieved from http:// facultyfocus.com.

Vonderwell, S. (2004). Assessing online learning and teaching: Adapting the minute paper. TechTrends, 48(4), 29-31.

Vonderwell, S., \& Boboc, M. (2013). Promoting formative assessment in online teaching and learning. TechTrends, 57(4), 22-27.

\section{Appendix A}

\section{EXAMPLE 1}

\section{CWV-101 Module 1 Quiz / Poll:}

Below are 7 questions designed to help us think in terms of how a worldview can affect perceptions and actions. Please respond to these questions by . (Record your impressions as a reply to this post.) There is no "right" or "wrong" answer to these questions; therefore, the responses should reflect your honest impressions. I will tabulate the results and post the class averages to the DQ Forum on

along with the ideas behind the questions. This quick quiz / poll is not mandatory and will not be graded; but, responses will count toward Participation Points.

1. Imagine your active and inquisitive 3 year old child is with you as you shop at a store that specializes in fine china and other glassware to purchase a wedding gift for a close friend / relative. The store openly displays all of its products; thus affording patrons the opportunity to inspect each piece by hand. The store also has a strict policy that "If you break it, you pay for it." Security cameras are positioned throughout the store to record everything that happens - allowing the store to enforce its policy. The child must accompany you into the store as you have no one available to watch him or her that day and you are out of time; the gift must be purchased today. What do you do? (Choose only the best answer.)

a. Let the child run free while you look around.

b. Keep a close eye on the child as you look around the store.

c. Warn the child repeatedly about touching anything as you try to look at the merchandise.

d. Warn the child prior to entering the store that he / she must not touch anything and keep the child close while in the store, issuing repeated warning each time you see him or her reach their hand out to touch an object.

e. Warn the child prior to entering the store, then pay no attention to what the child is doing while you shop.

2. You have purchased a ticket to an Arizona Diamondback baseball game from the Diamondback ticket office. Upon entering the stadium on the date for which you have a ticket, how confident are you your assigned seat will be available?

- very confident

- confident

- unsure

- unconfident

- very unconfident

3. T / F When you locate your seat you sit down without hesitation.

4a. Reality is different for each individual.

- strongly agree 
- agree

- undecided

- disagree

- strongly disagree

4b. Briefly explain your rationale.

5. Although scientific truth is established all other truth is relative.

- strongly agree

- agree

- undecided

- disagree

- strongly disagree

6. React to the following quote: "You are doing the right thing ... This is a great, powerful, and symbolic act ... O Century! O Science! It is a joy to be alive!" (Choose the best possible response.)

a. I agree; it is good to live in a time when science and scientific discovery are receiving their rightful recognition.

b. I don't know what it is, but something doesn't seem right about this statement.

c. Science and scientific discovery are good, but there is more to life than science.

7. Bonus question: Would knowledge of the speaker and the setting of question \#6 affect your answer?

a. Yes.

b. No.

c. Maybe.

\section{Appendix B}

\section{EXAMPLE 2}

\section{Module 1 Quiz / Poll Results:}

First, I want to thank everyone who participated in this brief quiz. I hope you had some fun and had your thinking stretched in the process. Below is the rationale behind the questions followed by the class results.

The Rationale behind the questions:

Question \#1 addresses real life situations - reality.

Questions \#2 \& 3 address assumptions.

Questions \#4 \& 5 address perspectives.
Questions \#6 \& 7 address source \& context.

The results:

Question \#1 -

a. -

b. -

c. -

d. -

e. -

Question \#2-

- were very confident the seat would be available.

- were confident the seat would be available.

- were unsure if the seat would be available.

- were unconfident the seat would be available.

- were very unconfident the seat would be available.

Question \#3 -

- True.

- False.

Question \#4 -

"Reality is different for each individual."

- strongly agree

- agree

- undecided

- disagree

- strongly disagree

Sample Reasoning's: Below are my paraphrases of the explanations for your answers to \#4b.

"Reality" is different because (either strongly agree or agree):

- Perception different in children than it is adults.

- Different cultures view things differently.

- Differing desires.

- Differing perceptions.

- Differing beliefs.

- Everyone is their own person.

- Reality depends on the state of mind of the individual.

"Reality" is not different because (either disagree or strongly disagree):

- Reality is how things actually exist.

- Reality is cold, hard facts.

- Reality is absolute truth.

- There is one reality; people may think dif- 
ferently.

- Ultimate truth is established by God.

Question \#5 -

"Although scientific truth is established, all other truth is relative."

- strongly agree

- agree

- undecided.

- disagree

- strongly disagree

Question \#6-

The longer quote, its context, and the speaker are revealed below.

a. I agree; it is good to live in a time when science and scientific discovery are receiving their rightful recognition.

b. I don't know what it is, but something doesn't feel right about this statement.

c. Science and scientific discovery are good, but there is more to life than science.

Question \#7 -

Would knowledge of the speaker and the setting of the quote affect your answer?

- Yes

- No

- Maybe

Questions \#6 \& 7 - The longer quote:

"German men and women! The age of arrogant Jewish intellectualism is now at an end! . . You are doing the right thing at this midnight hour - to consign to the flames the unclean spirit of the past. This is a great, powerful, and symbolic act ... Out of these ashes the phoenix of a new age will arise ... O Century! O Science! It is a joy to be alive!" (Joseph Goebbels, 1933, as quoted in Bonhoeffer: Pastor, Martyr, Prophet, Spy, 2010, p. 162-163).

Now the context: These words were spoken by Joseph Goebbels to further inflame the crowds in 1933 as the Nazis burned the books of those they deemed unworthy. Among the authors of books burned by the Nazis that night were Helen Keller, Jack London, H. G. Wells, Erich Maria Remarque, Albert Einstein, Thomas Mann, Heinrich Heine and Sigmund Freud (Metaxas, 2010, p. 162). A look at the list illustrates that science and scientific discovery were not the defining criteria - thought and ethnicity determined who should be read and who should not be read. tion)

Some concluding thoughts: (Personal Reflec-

Take some time to reflect on your thought process as you answered these questions:

- Did you treat each question as an isolated case or did you try to find a link between the questions as you answered?

- What assumptions or preconceived ideas influenced your answers?

- As you think about your responses, is there any contradiction in your answers? (For example, did you assume a consistent reality in Questions 1,2, 3, and 5 - then assert that reality is different for each individual?)

For further thought:

- Would your answer to question \#4, "reality," have been different had I stipulated "ultimate reality" instead of merely "reality?" (I intentionally left this question vague to encourage thinking and analysis.)

- In responding to \#5, "scientific truth," did you impose the same standard on "scientific truth" that you imposed on other truth? (Scientific theory is not equivalent to "scientific truth;" a theory is being tested, a truth has been tested.)

- Finally - Did you enjoy the exercise?

\section{REFERENCE}

Metaxas, E. (2010). Bonhoeffer: Pastor, martyr, prophet, spy. Nashville, TN: ThomasNelson. 


\section{Author Biography}

Ron Steadman joined Grand Canyon University in 2010 as an adjunct in the College of Theology. Ron currently teaches Christian Worldview. He has also taught Old and New Testament Historical Perspective and Biblical Interpretation and Application. Ron was recognized as distinguished faculty by GCU in August of 2012. Ron graduated from Liberty Baptist Theological Seminary with an MA in Theology. He earned his undergraduate degree from Colorado Christian University. His article, "God the I AM" was published in the Canyon Journal of Interdisciplinary Studies in December of 2012 . 